\title{
Correction to: Landslide susceptibility mapping of the Sera River Basin using logistic regression model
}

\author{
Nussaibah B. Raja ${ }^{1} \cdot$ Ihsan Çiçek $^{1}$ - Necla Türkoğlu ${ }^{1} \cdot$ Olgu Aydin $^{1}$ (D) \\ Akiyuki Kawasaki ${ }^{2}$
}

Published online: 21 December 2017

(C) The Author(s) 2017. This article is an open access publication

\section{Correction to: Nat Hazards (2017) 85:1323-1346 https://doi.org/10.1007/s11069-016-2591-7}

The article "Landslide susceptibility mapping of the Sera River Basin using logistic regression model," written by Nussaïbah B. Raja, Ihsan Çiçek, Necla Türkoğlu, Olgu Aydin, and Akiyuki Kawasaki, was originally published Online First without open access. After publication in volume 85, issue 3, pages 1323-1346, the author decided to opt for Open Choice and to make the article an open access publication. Therefore, the copyright of the article has been changed to (C) The Author(s) 2017, and the article is forthwith distributed under the terms of the Creative Commons Attribution 4.0 International License (http:// creativecommons.org/licenses/by/4.0/), which permits use, duplication, adaptation, distribution and reproduction in any medium or format, as long as you give appropriate credit to the original author(s) and the source, provide a link to the Creative Commons license, and indicate if changes were made.

Open Access This article is distributed under the terms of the Creative Commons Attribution 4.0 International License (http://creativecommons.org/licenses/by/4.0/), which permits unrestricted use, distribution, and reproduction in any medium, provided you give appropriate credit to the original author(s) and the source, provide a link to the Creative Commons license, and indicate if changes were made.

The original article can be found online at https://doi.org/10.1007/s11069-016-2591-7.

Olgu Aydin

oaydin@ankara.edu.tr; drolguaydin@gmail.com

1 Department of Geography, Faculty of Humanities, Ankara University, 06100 Sihhıye/Ankara, Turkey

2 Department of Civil Engineering, The University of Tokyo, Tokyo 153-8505, Japan 